\title{
DNA FINGERPRINTS OF THE ASIAN ELEPHANT IN SRI LANKA, ELEPHAS MAXIMUS MAXIMUS, USING MULTILOCUS PROBE 33.15 (JEFFREYS)
}

\author{
HIMESHA VANDEBONA ${ }^{1}$, MAYA B. GUNASEKERA ${ }^{1 *}$, W.D. RATNASOORIYA ${ }^{2}$, \\ NALIN C.W. GOONESEKERE ${ }^{1}$, D.S. KODIKARA ${ }^{3}$ and J. ALAHAKOON ${ }^{4}$. \\ ${ }^{I}$ Department of Chemistry, Faculty of Science, University of Colombo, Colombo 3. \\ ${ }^{2}$ Department of Zoology, Faculty of Science, University of Colombo, Colombo 3. \\ ${ }^{3}$ Animal Clinic, Kohuwela. \\ - National Zoological Gardens, Dehiwela.
}

(Received: 21 April 2004; accepted: 25 September 2004)

\begin{abstract}
The elephant in Sri Lanka, with a population estimated to be about 4,000 at present, is threatened by the loss of its jungle habitat due to human activity centred around the development programmes of the country. The wild elephant population is fragmented, and restricted to a few isolated small habitats in protected areas. The maintenance of a high degree of genetic diversity within elephant subpopulations is vital for its long-term survival. Monitoring the degree of genetic heterogeneity in the geographical sub-populations of elephant is therefore an essential pre-requisite for this purpose. Although the maternal lineage of the elephant population in Sri Lanka has been examined previously, nuclear DNA has not been examined to gather complementary information. The aim of this study was to develop the methodology to obtain nuclear DNA fingerprints of the elephant with the multilocus human DNA probe 33.15 (Jeffreys), and to evaluate the probe to study the degree of genetic heterogeneity in the elephant population. A unique DNA fingerprint was obtained for each elephant DNA sample under the optimized conditions of hybridization $\left(61^{\circ} \mathrm{C}\right.$ in buffer containing $0.25 \mathrm{M}$ sodium phosphate, 7\% SDS, $1 \%$ BSA, 6\% PEG, $10 \mathrm{mM}$ EDTA and $0.25 \%$ dried milk, $100 \mathrm{ng} / 15 \mathrm{ml}$ probe) developed during the study. A pair-wise comparison of DNA banding patterns of 8 individuals in the $3-23 \mathrm{~kb}$ region revealed a mean band sharing coefficient of $0.307 \pm 0.085$. A total of 57 variable banding positions were observed and the mean number of bands per individual was $19 \pm 2.14$. The calculated heterozygosity values for the unrelated and related individuals were 0.73 , and 0.57 (mean) respectively. The study clearly demonstrated that the 33.15 probe is highly suitable to monitor the degree of genetic heterogeneity in the geographical sub-populations of the Asian elephant.
\end{abstract}

Key words: Asian elephant in Sri Lanka, DNA fingerprint, Elephas maximus maximus, multilocus human DNA probe 33.15.

\section{INTRODUCTION}

The Asian elephant, Elephas maximus, is listed under CITES index I as an 'endangered' species ${ }^{1}$ and predicted to become extinct in the near future, unless intensive conservation programmes are implemented without delay. The Sri Lankan elephant population has declined substantially since the turn of the $19^{\text {th }}$ century,

\footnotetext{
"Corresponding author
} 
when an estimated 12,000 animals inhabited most of the island. ${ }^{2}$ Today, the elephant population in Sri Lanka is estimated to be about 4000 in the wild, ${ }^{3,4}$ and about 300 in captivity. ${ }^{5}$ This decline in the elephant population is attributed mainly to loss of jungle habitat due to human activity centered on the development programmes of the country. The remaining wild elephant population is fragmented and restricted to a few isolated small habitats. Recent studies on the analysis of the maternal lineage of the elephant population in Sri Lanka by mtDNA sequence divergence data of the control region ${ }^{6}$ and cytochrome $b$ gene and $\mathrm{NADH}$ dehydrogenase subunit 5 genes ${ }^{7}$ have revealed significant differences in mtDNA haplotype frequencies among geographical regions. This indicates limited genetic exchange among local sub-populations at present and that the population is under threat from inbreeding if habitat fragmentation is to persist or to increase further. These mtDNA studies have highlighted the importance of gathering complementary information utilizing nuclear DNA markers since nuclear data would reveal the genetic contribution of both parents. More recent evidence ${ }^{8}$ for the existence of two species of the African elephant, based on DNA sequence analysis of four nuclear genes, also demonstrates the importance of nuclear data for population genetic studies.

Nuclear DNA fingerprinting, a technique based on the identification of variable regions in the DNA of a species, is still a widely applicable tool to determine the effects of inbreeding, and to assess the genetic structure of small isolated populations. ${ }^{9}$ Nuclear DNA fingerprinting has been used to assess the degree of genetic variation both within, as well as between, geographical populations. The multilocus human DNA probe $33.15^{9}$ has been used successfully for the populationgenetic structure assessment of a large number of animal populations..$^{10-13}$ However, to obtain a successful fingerprint of the animal, the procedures described in these studies varied from one study to another and in some instances, from one animal to another. It had also been observed that the 33.15 probe is not appropriate to assess the degree of genetic variation in certain animals such as sheep, goats, pigs and cows due to the high band sharing coefficient values observed in these populations. ${ }^{12}$ The elephant however, has not been examined previously by this probe. Here, we report the development of methodology to obtain DNA fingerprints of elephants using the multilocus probe 33.15 , and demonstrate that the 33.15 probe is suitable for monitoring the degree of genetic heterogeneity in the geographical subpopulations of the Asian elephant in Sri Lanka.

\section{METHODS AND MATERIALS}

Collection of blood samples: Elephant blood samples were obtained from captive elephants $(n=10)$ of private owners and of the Captive Breeding Centre, Pinnawela elephant orphanage. The samples included two elephant families in the Pinnawela elephant orphanage of which three members were elephant calves born in captivity. All captive elephant samples with the exception of the three calves, have been 
captured from the wild and presumed to be unrelated. The geographic origin of five of these elephants was known: two were from the Northern region, two were from the Mahaweli region and one was from the Southern region of Sri Lanka. Blood samples (5 -20 ml) were collected under aseptic conditions from a vein on the underside of the ear of elephants into sterile tubes containing Acid Citrate Dextrose (ACD) buffer [citric acid $0.48 \%(\mathrm{w} / \mathrm{v})$, sodium citrate $1.32 \%(\mathrm{w} / \mathrm{v})$, glucose $1.47 \%(\mathrm{w} /$ v)], in the ratio of 1:6 of ACD to fresh blood. ${ }^{14}$ The cell pellet was separated within $12 \mathrm{~h}$ by centrifugation at $3500 \mathrm{~g}$ for $15 \mathrm{~min}$ and was stored at $-70^{\circ} \mathrm{C}$ in $1.5 \mathrm{ml}$ aliquots. Genomic DNA was isolated from frozen blood cells as described by Sambrook et $a l .{ }^{14}$ The cell pellet was washed in ice-cold Phosphate Buffered Saline (PBS) ( $\mathrm{pH} 7.4$ ), and lysed in two volumes of buffer containing $10 \mathrm{mM}$ Tris. $\mathrm{HCl}$ ( $\mathrm{pH}$ 8.0), $100 \mathrm{mM}$ EDTA (pH 8.0), $20 \mu \mathrm{g} / \mathrm{ml}$ RNAse, $0.5 \%$ (w/v) SDS at $37^{\circ} \mathrm{C}$ for 1 hour. Proteinase $\mathrm{K}(100 \mu \mathrm{g} / \mathrm{ml})$ was added and incubated at $50^{\circ} \mathrm{C}$ for $3 \mathrm{~h}$ and a further incubation at $37^{\circ} \mathrm{C}$ for $16 \mathrm{~h}$ with periodical swirling. DNA was extracted twice with a solution containing phenol ( $\mathrm{pH} 8.0) /$ chloroform/isoamyl alcohol (25:24:1) and twice with chloroform/isoamyl alcohol (24:1). The DNA was recovered by precipitation with two volumes of ethanol in the presence of $0.2 \mathrm{vol}$ of $10 \mathrm{M}$ ammonium acetate. The DNA was spooled out with a glass rod and dissolved in TE buffer ( $\mathrm{pH} \mathrm{8.0)}$. The quantity and the purity of each DNA sample were determined by measuring the absorbance at $260 \mathrm{~nm}$ and $280 \mathrm{~nm}$ by UV spectrophotometry (Cecil 2000, U.K). The degree of DNA degradation was checked by $0.8 \%$ agarose gel electrophoresis. The DNA extracted and purified from human blood, following the same procedure, was used as a control.

Restriction enzyme digestion and gel electrophoresis of DNA: Varying amounts of DNA $(2,5$ and $10 \mu \mathrm{g})$ from elephant and human blood samples were digested separately with restriction enzyme Hinf I (Roche Diagnostics, Germany) by incubating for approximately $16 \mathrm{~h}$ in a five fold excess of enzyme in a total volume of $100 \mu \mathrm{l}$. After examining a $200 \mathrm{ng}$ sample for complete digestion by $0.8 \%$ agarose gel electrophoresis, the DNA was precipitated with ethanol and dissolved in $16 \mu \mathrm{l}$ of TE buffer ( $\mathrm{pH}$ 8.0). The samples were then subjected to electrophoresis $(0.8 \%$ agarose gel, $17 \times 20 \mathrm{~cm}$ ) in $1 \times$ TBE buffer (0.09 M Tris-Borate and $0.002 \mathrm{M}$ EDTA) for $21 \mathrm{~h}$. The gel was stained with ethidium bromide and photographed under $\mathrm{UV}$ light. Lambda phage DNA digested with restriction endonuclease Hind III and end-labelled with ${ }^{32} \mathrm{P}$ was used as a molecular weight marker. ${ }^{14}$

Southern transfer and hybridization: The DNA samples (both elephant and the human controls) in the gel were depurinated by treatment with $0.25 \mathrm{M} \mathrm{HCl}$ for 10 min and denatured using a solution of $1.5 \mathrm{M} \mathrm{NaCl}, 0.5 \mathrm{M} \mathrm{NaOH}$, for $2 \times 20 \mathrm{~min}$ Two different methods were used in the Southern transfer. ${ }^{15}$ In one method, the gel was neutralized with $1 \mathrm{M}$ ammonium acetate buffer containing $0.02 \mathrm{M} \mathrm{NaOH}$ for $2 \times 30 \mathrm{~min}$ and Southern transferred according to the simplified procedure of Scaife \& Goman ${ }^{16}$. In the other method, the gel was neutralized in a solution containing 1.5 M NaCl, 0.5 M Tris. $\mathrm{HCl}$ ( $\mathrm{pH}$ 7.2) and 0.001 M EDTA for 2 x $30 \mathrm{~min}$ 
and Southern transferred with either $10 \mathrm{xSC}$ ( $1.5 \mathrm{M} \mathrm{NaCl}, 0.15 \mathrm{M}$ sodium citrate) or 20x SSC buffers. ${ }^{12}$ The DNA was allowed to capillary transfer for $19 \mathrm{~h}$ on to a charge modified nylon membrane (N0144, Sigma, USA). The efficiency of the Southern transfer was investigated by examining the agarose gel under UV immediately following the transfer, by re-staining with ethidium bromide for any remaining DNA fragments. The nylon membranes were washed in $2 \mathrm{x}$ SSC and baked for $90 \mathrm{~min}$ at $80^{\circ} \mathrm{C}$ to bind the DNA to the filter. A BamHI-KpnI DNA insert of the multilocus human DNA probe 33.15 (kind courtesy of Professor A.J. Jeffreys), was oligo-labelled ${ }^{17}$ with alpha- ${ }^{32} \mathrm{P}$ dATP (specific activity $\sim 10^{9} \mathrm{cpm} / \mu \mathrm{g}$ of DNA). The probe was purified by sephadex column chromatography, ${ }^{14}$ denatured by boiling for 10 min cooled in ice, prior to its use in filter hybridizations. As stated in Table 1 , several prehybridization/ hybridization buffers (HB) were prepared based on published protocols (some with slight modifications), and tested in order to obtain good DNA profiles. The first three Buffers (HB1-HB3) prepared were based on published protocols described for human ${ }^{12}$ and bird ${ }^{11,18}$ and were modified by adding various blocking agents (Denharts, heparin, dried milk powder). The next set of buffers (HB4-HB5) were prepared according to the procedures described for the fox ${ }^{19}$ and the whale ${ }^{13}$ DNA, respectively. Based on the results of these experiments another set of buffers (HB6-HB9) were prepared by varying the concentrations of both the salt and the blocking agent. Prehybridization and hybridization were performed at $61^{\circ} \mathrm{C}$ for $20 \mathrm{~h}$ in a dry-air incubator, without shaking. The optimum probe concentration was determined by performing hybridization with varying concentrations of probe ( $25 \mathrm{ng}-100 \mathrm{ng} / 15 \mathrm{ml}$ per $5 \times 17 \mathrm{~cm}$ filter). Filters were washed twice in $3 \times$ SSC, $0.1 \%$ SDS for 5 min each with vigorous shaking at $58^{\circ} \mathrm{C}$. A final wash was performed in $3 \mathrm{x} \mathrm{SSC}$ at $58^{\circ} \mathrm{C}$ for $5 \mathrm{~min}$. The air dried filter was covered with saran wrap and autoradiographed ${ }^{14}$ at $-70^{\circ} \mathrm{C}$ for $3-14$ days with a Xray film (Kodak XK-5) with two intensifying screens.

DNA fingerprint analysis: A pair-wise comparison of banding patterns was performed. The band assignments were made after manual examination of autoradiographs. These images were then scanned and processed using computer software (Adobe photoshop version 4.0) and the manual assignments were verified and band distances accurately measured. The band sharing coefficient, $\mathrm{S}$, was calculated using the formula $2 \mathrm{~N} /(\mathrm{Na}+\mathrm{Nb})$ where $\mathrm{Na}$ and $\mathrm{Nb}$ are the number of fragments in individuals $a$ and $b$, and $N$ is the number of fragments shared by both $\mathrm{a}$ and $\mathrm{b} \cdot{ }^{9,20}$

Based on DNA fingerprint data, the heterozygosity $(\mathrm{H})$ within populations was calculated by the equation,

$$
\mathrm{H}=\frac{\sum_{k=1}^{A} S K}{A-\sum_{k=1}^{A} \sqrt{1-S K}}-1
$$


where $S_{k}$ is the frequency of occurrence of the $k^{\text {th }}$ band and $A$ is the total number of scorable bands on the gel. ${ }^{13,21}$

Heterozygosity was calculated for unrelated individuals $(n=5)$ and for two families $(n=4$ and $n=3$ ) separately.

Table 1: Composition of prehybridization/hybridization buffers (HB) used for the optimization assay.

\begin{tabular}{|c|c|c|c|c|c|c|c|c|c|}
\hline \multirow[t]{2}{*}{ BUFFER } & \multicolumn{2}{|c|}{ SALT $^{a}$} & \multicolumn{5}{|c|}{ BLOCKING AGENTS $^{b}$} & \multicolumn{2}{|c|}{ POLY $^{\mathrm{c}}$} \\
\hline & SSC & $\mathrm{SP}$ & SDS & DEN & DMP & HEP & BSA & EDTA & PEG \\
\hline $\mathrm{HB}^{1}{ }^{1}$ & $1 \mathrm{x}$ & - & $1 \%$ & $2 x$ & - & $100 \mu \mathrm{g} / \mathrm{ml}$ & - & - & $6 \%$ \\
\hline $\mathrm{HB}^{2}{ }^{2}$ & $1 \mathrm{x}$ & - & $1 \%$ & - & $0.5 \%$ & - & - & - & $6 \%$ \\
\hline $\mathrm{HB}^{3}{ }^{3}$ & $1.5 \mathrm{x}$ & - & - & $5 x$ & - & - & - & - & $6 \%$ \\
\hline $\mathrm{HB}_{4}{ }^{4}$ & - & $0.5 \mathrm{M}$ & $7 \%$ & - & - & - & $1 \%$ & $1 \mathrm{mM}$ & - \\
\hline $\mathrm{HB}^{5}$ & - & $0.25 \mathrm{M}$ & $7 \%$ & - & - & - & $1 \%$ & $10 \mathrm{mM}$ & - \\
\hline HB6 & - & $0.25 \mathrm{M}$ & $7 \%$ & - & - & - & $1 \%$ & $10 \mathrm{mM}$ & $6 \%$ \\
\hline HB7 & - & $0.25 \mathrm{M}$ & $7 \%$ & - & $0.5 \%$ & - & $1 \%$ & $10 \mathrm{mM}$ & $6 \%$ \\
\hline HB8 & - & $0.10 \mathrm{M}$ & $7 \%$ & - & $0.25 \%$ & - & $1 \%$ & $10 \mathrm{mM}$ & $6 \%$ \\
\hline HB9 & - & $0.25 \mathrm{M}$ & $7 \%$ & - & $0.25 \%$ & - & $1 \%$ & $10 \mathrm{mM}$ & $6 \%$ \\
\hline
\end{tabular}

${ }^{a} \mathrm{SP}=$ sodium phosphate $(\mathrm{pH} 7.2) ; \mathrm{SSC}=$ sodium chloride - sodium citrate

${ }^{b} \mathrm{SDS}=$ sodium dodecyl sulphate; $\mathrm{DEN}=$ Denhardts $(50 \mathrm{x}$ Denhardts $=1 \%$ ficoll, $1 \%$ poly vinyl pyrollidone, $1 \%$ bovine serum albumin (BSA); DMP = non-fat dried milk powder (Anchor); HEP = Heparin

${ }^{\mathrm{C}} \mathrm{POLY}=$ polymer $; \mathrm{PEG}=$ polyethylene glycol

1. Modified from Burke \& Bruford ${ }^{18}$ for birds; 2. According to Kirby ${ }^{12} ; 3$. Modified from Wetton et al..$^{11}$ for house sparrow; 4. Gilbert et al. ${ }^{19}$ for fox; 5 . Baker et al. ${ }^{13}$ for whale.

\section{RESULTS}

\section{Development of DNA fingerprinting methodology for the elephant}

The summary of the results obtained for the development of DNA fingerprinting methodology for the elephant using radio-labelled DNA probe 33.15 is presented in Table 2. In the first set of experiments (HB1-HB3) the amount of elephant DNA was varied between $2-10 \mu \mathrm{g}$. The concentration of probe was kept constant at $50 \mathrm{ng} / 15 \mathrm{ml}$ of HB buffer. HB1 (containing heparin and 2x Denharts as blocking agents) and HB3 (with 5x Denharts) failed to give a DNA banding pattern for either elephant or human DNA. In contrast, HB2, which contained dried milk powder as blocking agent, revealed a faint banding pattern with $10 \mu \mathrm{g}$ of elephant DNA. (Figure 1a). Thus, a minimum quantity of $10 \mu \mathrm{g}$ of restricted DNA is required to visualize a 


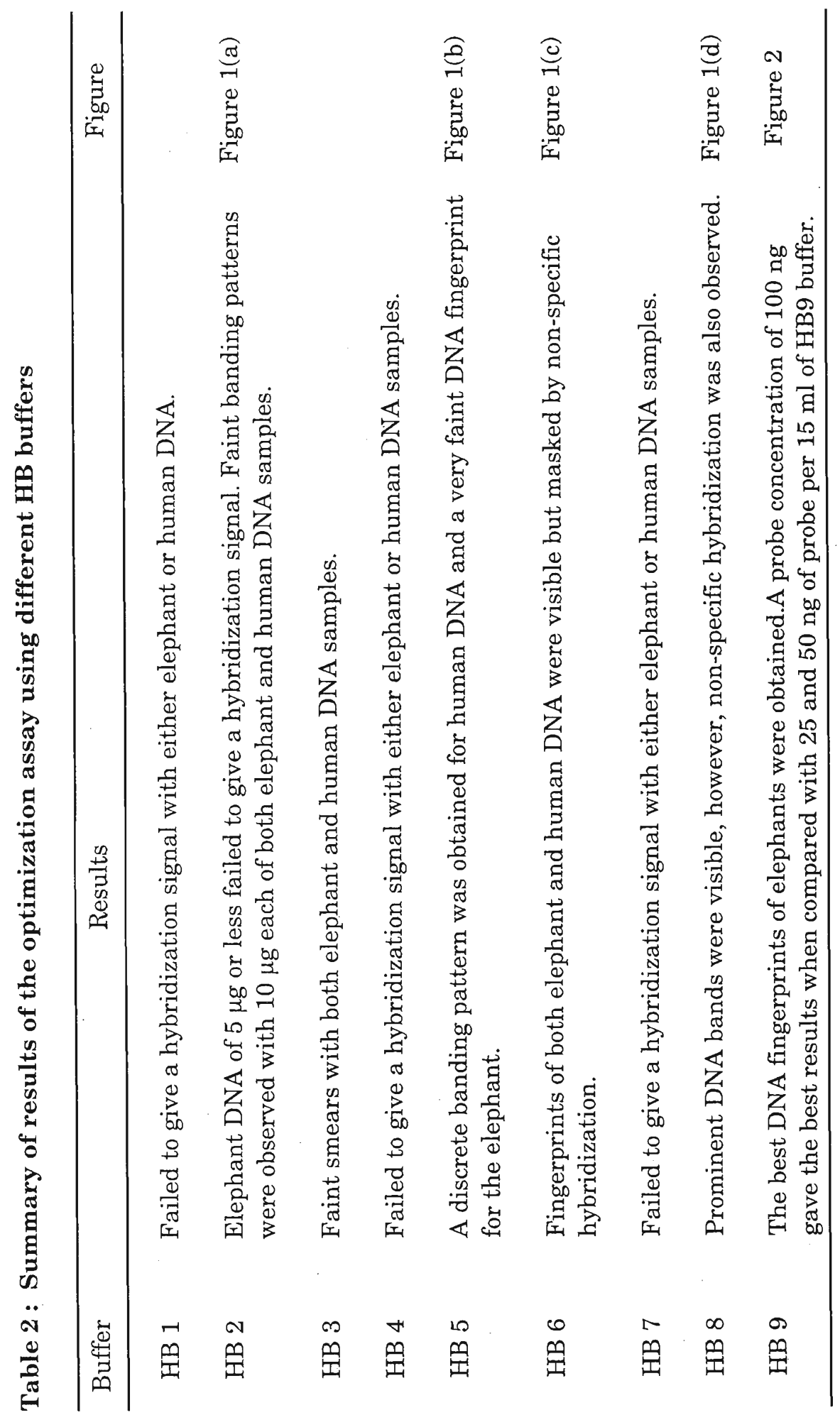


DNA profile of the elephant. Of the three Southern transfer buffers tested, complete transfer of DNA was only achieved by using 20x SSC buffer.

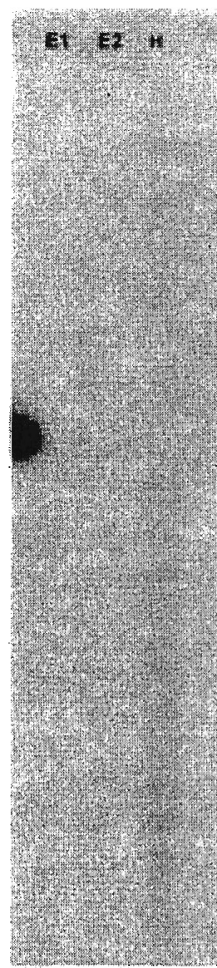

(a) HB2

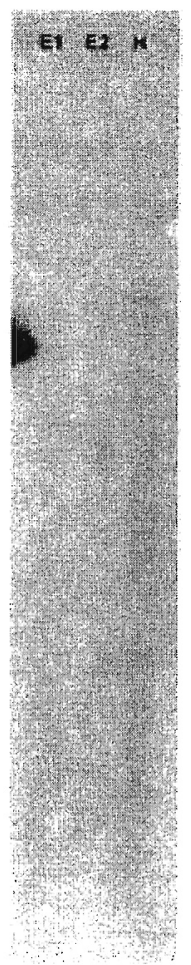

(b) HB5

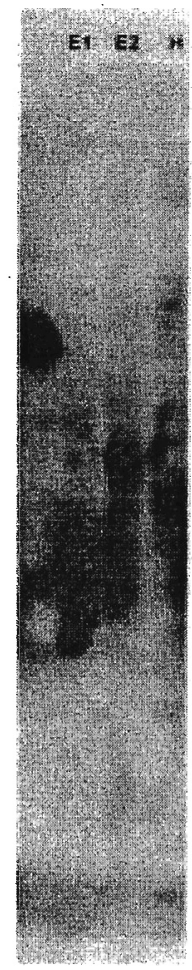

(c) HB6

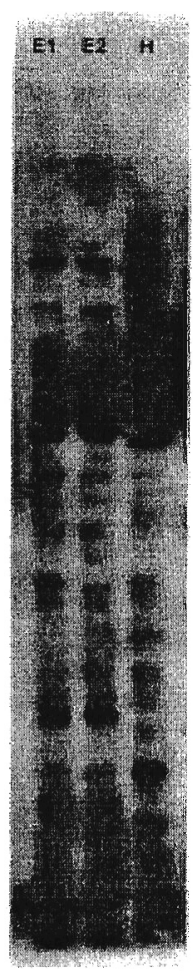

(d) HB8

Figure 1: Southern hybridization of DNA with $50 \mathrm{ng} / 15 \mathrm{ml}$ of radiolabelled 33.15 probe in (a) HB2 buffer (b) HB5 buffer (c) HB6 buffer (d) HB8 buffer, at $61^{\circ} \mathrm{C}$. Autoradiography was performed for 7 days. $E_{1}$ and $E_{2}=$ Elephant DNA samples, $10 \mu \mathrm{g}$ each; $\mathrm{H}=$ Human DNA, $10 \mu \mathrm{g}$.

In the second set of experiments, HB4 and HB5 were tested. The amount of DNA and the concentration of probe were kept constant at $10 \mu \mathrm{g}$ and $50 \mathrm{ng} / 15$ $\mathrm{ml}$ of $\mathrm{HB}$ buffer, respectively. SSC (20x) was used as the Southern transfer buffer. HB4 failed to give a hybridization pattern with filter DNA. However, HB5 buffer gave a faint banding pattern for the elephant DNA (Figure 1b). HB6 buffer (6\% PEG added to HB5 buffer to increase the hybridization rate by concentrating the probe) revealed more prominent.DNA bands, but also led to high background (Figure 1c). Therefore, HB6 buffer was further tested by the addition of varying concentrations of dried milk powder and by varying the salt concentration. To this end; three more buffers were prepared. One buffer contained $0.5 \%$ dried milk powder in $0.25 \mathrm{M}$ sodium phosphate (=HB7). Two buffers contained $0.25 \%$ dried milk, one in $0.1 \mathrm{M}$ sodium phosphate (=HB8), and the other in $0.25 \mathrm{M}$ sodium phosphate (=HB9): HB7, which contained more milk than the other two buffers, completely 
blocked the hybridization of probe with the filter DNA, by giving a negative hybridization signal. Prominent DNA bands were observed with HB8. However, background hybridization was also high (Plate Id) in HB8. HB9 gave the best DNA profile (Figures $2 \& 3$ ).

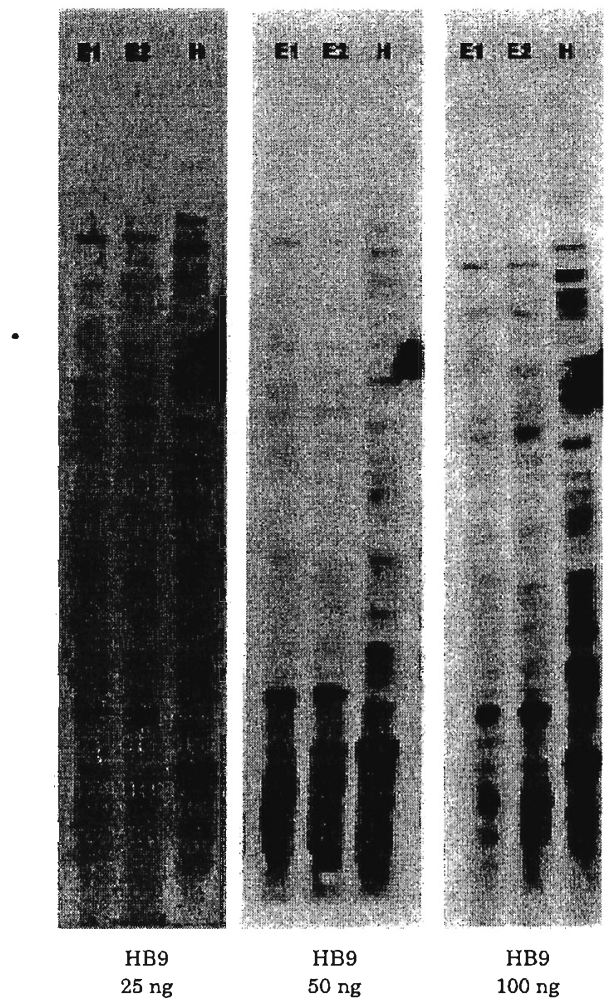

Figure 2 : Southern hybridization of DNA with varying concentrations of radiolabelled 33.15 probe to determine the optimum probe concentration required to obtain a DNA fingerprint. Hybridization was performed in 15 $\mathrm{ml}$ of HB9 at $61^{\circ} \mathrm{C}$, with either $25 \mathrm{ng}, 50 \mathrm{ng}$ or $100 \mathrm{ng}$ of radiolabelled 33.15 probe. Autoradiography was performed for 7 days. $E_{1}$ and $E_{2}=$ Elephant DNA samples, $10 \mu \mathrm{g}$ each; H= Human DNA, $10 \mu \mathrm{g}$.

In the final set of experiments that were performed to determine the optimum probe concentration, a $100 \mathrm{ng}$ of probe per $15 \mathrm{ml}$ of HB9 buffer (optimized buffer), gave the best banding pattern, when compared to lower concentrations (25 and $50 \mathrm{ng} / 15 \mathrm{ml}$ ) of probe (Figure 2). The filters needed to be autoradiographed for at least 3 days to observe a banding pattern. A 10 day exposure (Figure 3 ) revealed a very prominent DNA fingerprint that could be analysed without any ambiguity. Hence, the optimized hybridization conditions developed for DNA fingerprint analysis of elephant using radiolabelled 33.15 probe are prehybridization at $61^{\circ} \mathrm{C}$ in buffer HB9 (containing 0.25 M sodium phosphate, 7\% SDS, 1\% BSA, 6\% PEG, 
$10 \mathrm{mM}$ EDTA and $0.25 \%$ dried milk) and hybridization also at $61^{\circ} \mathrm{C}$ in the same buffer with a probe concentration of $100 \mathrm{ng} / 15 \mathrm{ml}$.

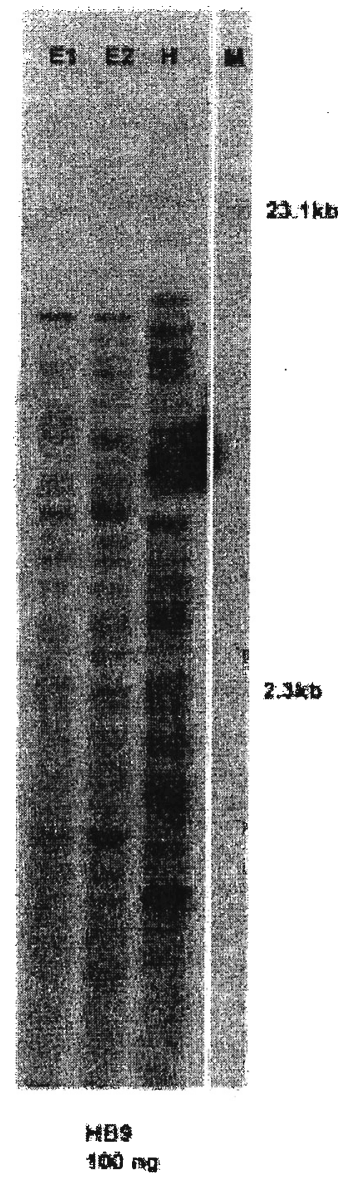

Figure 3 : DNA fingerprints obtained under the optimized conditions. Hybridization was performed in $15 \mathrm{ml}$ of $\mathrm{HB9}$ buffer at $61^{\circ} \mathrm{C}$, with $100 \mathrm{ng}$ of radiolabelled 33.15 probe. The filter was washed in $3 \times$ SSC, $0.1 \%$ SDS at $58^{\circ} \mathrm{C}$ and autoradiographed for 10 days. $E_{1}$ and $E_{2}=$ Elephant DNA samples, $10 \mu \mathrm{g}$ each; $\mathbf{H}=$ Human DNA, $10 \mu \mathrm{g}$.

Suitability of multilocus probe 33.15 for the population-genetic structure analysis of the elephant

Eight elephant DNA samples were fingerprinted using the above procedure and a unique DNA profile was obtained for each individual (fingerprints not shown). The mean number of bands observed per individual was $19 \pm 2.14$ and a total of 57 variable banding positions were found in the $3-23 \mathrm{~kb}$ region. A pair-wise comparison 
of banding patterns in the same region revealed a mean band sharing coefficient of $0.307 \pm 0.085$. Based on the elephant DNA fingerprint data, the calculated heterozygosity for unrelated individuals $(n=5)$ was 0.73 . Heterozygosity was separately calculated also for two elephant families from the Pinnawela elephant orphanage where the family relationships were known. The heterozygosity value obtained for the family which comprised an elephant bull, a dam, and a calf, $(n=3)$ was 0.58 , while the other family which comprised in addition, an extra calf $(n=4)$, had a comparable heterozygosity value of 0.56 .

\section{DISCUSSION}

The optimum conditions for DNA fingerprint analysis of the elephant, with radiolabelled multilocus DNA probe 33.15 , were determined empirically by varying several experimental parameters. These include the amount of DNA in the Southern blot, the composition of Southern transfer buffer and prehybridization/hybridization buffers, the concentration of radiolabelled probe, and the duration of autoradiography. The Southern transfer and hybridization were performed without the use of special equipment such as a vacublot apparatus and a hybridization oven shaker, and the hybridization assay was optimized to suit these laboratory conditions. The prehybridization/hybridization buffers (HB1-HB9) were determined by varying the salt concentration (1.5-1x SSC, $0.5 \mathrm{M}-0.1 \mathrm{M}$ sodium phosphate), the blocking agents (Denharts, BSA, heparin, dried milk, SDS) and by the inclusion (or exclusion) of polyethyleneglycol in the buffer. The stringency of hybridization conditions was varied by changing the salt concentration, while keeping the temperature a constant $\left(61^{\circ} \mathrm{C}\right)$. The published protocols for DNA fingerprint analysis of the whale ${ }^{13}$ and the fox ${ }^{19}$ were not successful in yielding a usable DNA fingerprint of the elephant. However, the inclusion of $6 \%$ polyethylene-glycol and $0.25 \%$ dried milk in the buffer described for whale ( $0.25 \mathrm{M}$ sodium phosphate), greatly enhanced the hybridization process by giving a prominent banding pattern while reducing non-specific hybridization. Reducing the sodium phosphate concentration from 0.25 $\mathrm{M}$ to $0.1 \mathrm{M}$ also gave a good DNA profile due to less stringent hybridization conditions, but led to high background, possibly because phosphate also acts as a blocking agent. Dried milk was found to be a more suitable and a cheaper alternative to other commonly used blocking agents such as Denharts and heparin. As DNA fingerprinting technology continues to play an important role in behavioral and evolutionary ecology, particularly in studies of parentage, ${ }^{22-25}$ the methodology to obtain high quality DNA fingerprints as described here, could also be utilized to design and develop procedures for other animal populations previously not analysed by this technology.

Previous studies ${ }^{12}$ have demonstrated that the multilocus probe 33.15 is inappropriate for use with some animals. However, our results show that this probe is appropriate for use with the elephant. The only other published work on DNA Iingerprint analysis of the elephant ${ }^{26}$ had used the multilocus M13 DNA probe. ${ }^{27}$ This study has shown the presence of an average of only $8.61 \pm 1.88$ DNA bands per individual, compared to $19 \pm 2.14$ observed in our study. Since the band sharing 
coefficients in both studies were similar ( $<0.38$ with M13 DNA probe, for unrelated individuals), our results clearly demonstrate that the probe 33.15 is more suited to assess the level of inbreeding in an elephant population by DNA fingerprint analysis as it permits the scoring of more DNA banding positions.

The heterozygosity calculated for the elephant population in this study was 0.73 , a value lower than the human $(0.86)^{28}$ and the whale $(0.88-0.89)^{13}$ populations and higher than the domestic cat $(0.35-0.56)^{28}$ and the lion $(0.03-0.50)$ ${ }^{28}$ populations. This indicates that the present elephant population is not threatened by genetic factors and corroborates the previous findings based on mitochondrial DNA sequence data ${ }^{6,7}$ However, it is vital to analyze a larger number of samples from each elephant sub-population by DNA fingerprint analysis to estimate the genetic effect due to recent habitat fragmentation.

A few microsatellite or STR (short tandem repeat) DNA markers have also been developed ${ }^{29-31}$ and used for nuclear DNA typing of the African elephant. ${ }^{32}$ The STR markers designed for the African elephant, however, have been found to be less polymorphic in the Asian elephant. ${ }^{30,31}$ Hence, several such STR markers need to be developed in order to determine the degree of genetic heterogeneity in the Asian elephant population.

\section{Acknowledgement}

We thank Professor A.J. Jeffreys for providing the multilocus 33.15 DNA probe. We greatly appreciate the co-operation extended to this study by the Director of the National Zoological Gardens, Sri Lanka, Mr. F.S.M. Seelaratne and Mr. S.K. Ratnayake of the Pinnawala elephant orphanage, and all elephant owners and mahouts. This work was supported by research grants from the International Foundation of Science (IFS) Research Grant No.s B/2342-1\& B/2342-2, and Department of Wild Life Conservation, Sri Lanka, Research Grant No. GEF/402/ 96, under the Global Environmnent Facility Project (GEF).

\section{References}

1 IUCN. (1996). 1996 IUCN Red list of threatened animals. IUCN. Gland.

2 McKay G. M. (1973). Behaviour and ecology of the Asiatic elephant in southeastern Ceylon. Smithsonian Contributions to Zoology 125: 1-113.

3 De Silva M. \& Atapattu N. (1997). Alleviation of wild elephant-human conflict and conservation of elephant in the north-western region of Sri Lanka. Department of Wildlife Conservation, Colombo (mimeo). 
4 De Silva M. (1998). Status and conservation of the elephant (Elephas maximus) and the alleviation of man-elephant conflict in Sri Lanka. Gajah 19: 1-68.

5 Jayewardene J. (1998). Captive elephants in Sri Lanka: status, distribution and numbers. Sri Lanka Nature 1(4) : 13-18.

6 Fernando P., Pfrender M. E., Encalada S. E. \& Lande R. (2000). Mitochondrial DNA variation, phylogeography and population structure of the Asian elephant. Heredity 84: 362-372.

7 Vandebona H., Goonesekere N.C.W., Tiedemann R., Ratnasooriya W.D. \& Gunasekera M.B. (2002). Sequence variation at two mitochondrial genes in the Asian elephant (Elephas maximus) population of Sri Lanka. Mammalian Biology 67: 1-13

8 Roca A. L., Georgiadis N., Pecon-Slattery J. \& O'Brien S. J. (2001). Genetic evidence for two species of elephant in africa. Science 293: 1473-1477.

9 Jeffreys A.J., Wilson V. \& Thein S.L. (1985). Individual specific fingerprints of human DNA. Nature 316: 76-79.

10 Jeffreys A.J., Hartley N., Bulfield G., Morton D., Wilson V., Wong Z. \& Harris S. (1987). The implications of hypervariable regions for animal identification. Animal Genetics 18: 141-142.

11 Wetton J. H., Carter R.E., Parkin D.T. \& Walters D. (1987). Demographic study of a wild house sparrow population DNA fingerprinting. Nature 327: 147-149.

12 Kirby L.T. (1990). DNA fingerprinting - An introduction. Stockton Press, N.Y.

13 Baker C.S., Gilbert D.A., Weinrich M.T., Lambertsen R., Calambokidis J., McArdle B., Chambers G.K. \& O'Brien S.J. (1993). Population characteristics of DNA fingerprints in Humpback whales (Megaptera novaeangliae). Journal of Heredity 84: 281-290.

14 Sambrook J., Fritsch E.F. \& Maniatis T. (1989). Molecular Cloning: A Laboratory Manual. (2nd edition). Cold Spring Harbor Laboratory, NY, USA.

15 Southern E.M. (1975). Detection of specific sequences among DNA fragments separated by gel electrophoresis. Journal of molecular biology 98: 503-515. 
16 Scaife J.G. \& Goman M. (1985). Construction of DNA library with phages. In: Application of genetic engineering to research on tropical diseases pathogens with special reference to plasmodia: a laboratory manual of selected techniques. (Eds. S.Panyim, P. Wilairat \& Y.Yuthavong) pp.101-141. World Health Organization Publication, Bangkok.

17 Feinberg A.P. \& Vogelstein B. (1983). A technique for radiolabelling DNA restriction endonuclease to high specific activity. Analytical Biochemistry 132: 6-13.

18 Burke T. \& Bruford M.W. (1987). DNA fingerprinting in birds. Nature 327: 149-152.

19 Gilbert D.A., Lehman N., O’Brien S.J. \& Wayne R.K. (1990). Genetic fingerprinting reflects population differentiation in the California Channel Island fox. Nature 344: 764-767.

20 Lynch M. (1990). The similarity index and DNA fingerprinting. Molecular biology and evolution 7(5): $478-484$.

21 Stephern J. C., Gilbert D.A., Yuhki N. \& O'Brien S.J. (1992). Estimation of heterozygosity for single probe, multilocus DNA fingerprints. Molecular Biology and Evolution 9: 729-743.

22 Gissing G. J., Crease T. J. \& Eadie J. McA. (1997). Optimized PCR labelling and hybridization conditions result in extremely fast, high quality, chemiluminescent DNA fingerprints. Biochemica 1: 23-24.

23 Marfori M. A., Parker P. G., Gregg T. G., Vandenbergh J. G. \& Solomon N. G. (1997). Using DNA fingerprinting to estimate relatedness within social groups of pine voles. Journal of Mammalogy 78(3): 715-724.

24 Travis S. E., Slobodchikoff C. N. \& Keim P. (1997). DNA fingerprinting reveals low genetic diversity in Gunnison's prairie dog (Cynomys gunnisoni). Journal of Mammalogy 78(3): 725-732.

25 Verboven N. \& Mateman C. (1997). Low frequency of extra-pair fertilizations in the great tit Parus major revealed by DNA fingerprinting. Journal of Avian Biology 28: 231-239.

26 Bischof L. \& Duffield D.A. (1994). Relatedness estimation of captive Asian elephants (Elephas maximus) by DNA fingerprinting. Zoo Biology 13: 77-82. 
27 Georges M., Lequarre A., Castelli M., Hanset R. \& Vassart G. (1988). DNA fingerprinting in domestic animals using four different minisatellite probes. Cytogenetics and Cell genetics 47: 127-131.

28 Gilbert D.A., Packer C., Pusey A. E., Stephens J. C. \& O’Brien S.J. (1991). Analytical DNA fingerprinting in Lions: parentage, genetic diversity and kinship. The Journal of Heredity 82 (5): 378-386.

29 Nyakaana S. \& Arctander P. (1998). Isolation and characterization of microsatellite loci in the African elephant, Loxodonta africana. Molecular Ecology 7(10): 1436-1437.

30 Comstock K. E., Wasser S. K. \& Ostrander E. A. (2000). Polymorphic microsatellite DNA loci identified in the African elephant (Loxodonta africana). Molecular Ecology 9 (7): 1004-1006.

31 Eggert L. S., Ramakrishnan U., Mundy N. I. \& Woodruff D. S. (2000). Polymorphic microsatellite DNA markers in the African elephant (Loxodonta africana) and their use in the Asian elephant (Elephas maximus) Molecular Ecology 9: 2155-2234.

32 Nyakaana S. \& Arctander P. (1999). Population genetic structure assessment of the African elephant in Uganda based on variation at mitochodrial and nuclear loci: evidence for male-biased gene flow. Molecular Ecology 8(7): 1105-1115. 